\title{
Is there a seasonal feature of new-onset atrial fibrillation after coronary artery bypass graft surgery?
}

\section{Koroner arter bypass greft cerrahisi sonrası yeni gelişen atrial fibrilasyonun mevsimsel özelliği var mıdır?}

\author{
Fatih Ada, Vurall Polat
}

Sivas Cumhuriyet University School of Medicine, Department of Cardiovascular Surgery, Sivas, Turkey

Corresponding author: Fatih Ada, MD, Sivas Cumhuriyet University School of Medicine, Department of Cardiovascular Surgery, Sivas, Turkey

E-mail: drfatihada@gmail.com

Received/Accepted: August 25, 2019 /September 28, 2019

Conflict of interest: There is not a conflict of interest.

\section{SUMMARY}

Objective: Atrial fibrillation (AF) is seen as very common after cardiac surgery. Postoperative AF occurrence increases mortality and morbidity. Deterioration of clinical condition of the patients results prolongation of hospital stay and increases economic burden. Many risk factors that have an impact on the development of postoperative AF are known. Low vitamin D level has been added to these factors in recent years. Blood serum levels of vitamin $\mathrm{D}$ is varied seasonally. Therefore, these factors can be expected to have a seasonal effect on development of postoperative AF. The aim of this study is to investigate the presence of annual features of postoperative AF. Method: This study is a retrospective analysis of patients who developed atrial fibrillation after coronary artery bypass graft surgery in the Cardiovascular Surgery Department of Sivas Cumhuriyet University between 2017 and 2019 years. The study started after decision of Sivas Cumhuriyet University Local Ethics Committee No. 2019-04/04. Preoperative, intraoperative and postoperative parameters of the patients were evaluated. 39 patients who developed atrial fibrillation after coronary artery bypass graft surgery included the study. Statistical analyses were performed according to the seasons of atrial fibrillation which developed after coronary artery bypass grafting.

Results: Postoperative AF development is observed seasonally most often in winter and less in summer. However, the seasonal incidence is similar in autumn and spring. On the other hand, postoperative AF was observed more frequently in males $(69,2 \%)$ than females $(30,8 \%)$.

Conclusions: Postoperative atrial fibrillation showed a seasonal difference. This difference supports the relationship between vitamin D deficiency/insufficiency and postoperative AF development.

Keywords: Atrial fibrillation, coronary artery bypass graft, season, surgery, vitamin D 
faktörlerin postoperatif AF gelişiminde mevsimsel etkiye yol açması beklenebilir. Bu çalışmada, postoperatif AF gelişiminin mevsimsel özelliğinin olup olmadığının araştırılması amaçlanmıştır.

Yöntem: Bu çalışma, 2017 - 2019 yılları arasında Sivas Cumhuriyet Üniversitesi Kalp Damar Cerrahisi Kliniğinde koroner arter baypas greft cerrahisi sonrası atriyal fibrilasyon gelişen hastaların retrospektif bir analizidir. Çalışmaya, Sivas Cumhuriyet Üniversitesi Yerel Etik Kurulunun 2019-04 / 04 sayılı kararı sonrası başlandı. Hastaların preoperatif, intraoperatif ve postoperatif parametreleri değerlendirildi. Çalışmaya koroner arter baypas greft ameliyatı sonrası atriyal fibrilasyon gelişen 39 hasta dâhil edildi. Koroner arter bypass greft sonrası atrial fibrilasyon gelişen hastaların mevsimlere göre istatistiksel analizleri yapıldı.

Bulgular: Postoperatif AF gelişimi mevsimsel olarak en sık kış mevsiminde en az yaz mevsiminde görülmektedir. Sonbahar ve ilkbahar mevsiminde görülme sıklıkları ise bir birine benzerdir. Öte yandan postoperatif AF'nin erkeklerde $(\% 69,2)$, kadınlardan $(\% 30,8)$ daha sık görüldüğü izlenmiştir.

Sonuç: Postoperatif AF'nin mevsimsel bir değişim gösterdiği izlenmiştir. Bu değişim D vitamini eksikliği ve postoperatif AF gelişimi arasındaki ilişkiyi destekler niteliktedir.

Anahtar sözcükler: Atriyal fibrilasyon, koroner arter bypass greft, mevsim, cerrahi, vitamin D

\section{INTRODUCTION}

The incidence of arrhythmia is between 10-53\% after cardiac surgery. The most common arrhythmia after cardiac surgery is atrial fibrillation, which increases mortality and morbidity and also causes prolonged hospital stay and deterioration of the patient's clinic. There are many reasons for AF after cardiac surgery. Hypertension, heart failure, chronic lung disease, right coronary artery lesion, coronary artery disease accompanied by valve diseases, metabolic changes are just a few of these factors. There were no reports in the literature regarding the seasonal characteristics of AF, which develops after coronary artery bypass graft surgery. Kupari et al. reported a study on the relationship between acute AF and low temperature. In this study, it was concluded that AF peaked in December and January and was minimal level in May and June ${ }^{1}$. Watanabe et al.'s study of the seasonal relationship between paroxysmal AF showed similar results ${ }^{2}$. However, both studies remaining an epidemiological study that did not mention the relationship between vitamin $\mathrm{D}$ in conclusion.

There are many publications in the literature on low vitamin $\mathrm{D}$ levels and postoperative $\mathrm{AF}^{3,4}$. In recent years, there are many publications in the literature regarding the relationship between vitamin D deficiency and postoperative AF development. In addition to the known risk factors, the relationship between vitamin D deficiency and the seasonal characteristics of $\mathrm{AF}$, which developed after coronary artery bypass graft surgery is an important issue to examine. In this study, we investigated whether there was a difference in $\mathrm{AF}$ seen after coronary artery bypass graft operation during the summer season when vitamin D levels were peak, and during the winter season when it was lowest.

\section{MATERIAL AND METHODS}

This study is a retrospective analysis of AF after coronary artery bypass graft surgery at Sivas Cumhuriyet University Cardiovascular Surgery Department between 2017- 2019 with the decision of the number 2019-04/04 of the Sivas Cumhuriyet University local ethics committee. The study included 39 patients who developed AF after coronary artery bypass graft surgery. The written consent form was obtained from all patients. Patient information was obtained from patient cards and the hospital registry system. The anamnesis of the patients was carefully taken, and the physical examinations were made to identify vascular and other pathological diseases.

Patients who had preoperative $\mathrm{AF}$, late $\mathrm{AF}$, combined cardiac surgery, and who used vitamin D for any reason before surgery were excluded from the study. Demographic data such as age, sex, habits (tobacco use), drugs, the season of operation, operational data (cross-clamp time, cardiopulmonary bypass time), echocardiography data (ejection fraction (EF), left atrial diameter) and laboratory data of the patients were evaluated. All these data were assessed according to seasonal characteristics of postoperative AF.

Statistical Analysis: In the study, continuous variables were expressed as mean $\pm \mathrm{SD}$ and categorical variables as frequency and percentage. SPSS 24 package statistical program (StataCorp LP, College Station, TX, USA) was used for descriptive statistics and CI calculations.

\section{RESULTS}

Between January 2017 and January 2019, a total of 412 aortocoronary bypass graft surgery was performed at our clinic. Of these surgeries; $33,4 \%$ were performed in the spring season, $22,5 \%$ in the autumn season, $22,1 \%$ in the winter season, and 
$22 \%$ in the summer season (Graph 1). Postoperative AF occurrence was found as follows; $17,5 \%(91 / 16)$ in winter, $8,6 \%(93 / 8)$ in autumn, $7,2 \%(138 / 10)$ in spring and 5,5\% (90/5) in summer. Of the patients who developed postoperative atrial fibrillation, $69,2 \%$ were male, $30,8 \%$ were female, and the mean age was $70,2 \pm$
7,9 (Table1). In the preoperative tests; mean potassium values were $4,26 \mathrm{mEq} / \mathrm{L}$, mean ejection fraction was $49,9 \%$ and mean left atrium diameters were $45,1 \mathrm{~cm} / \mathrm{m} 2$ (Table 2). The mean cross-clamp time was 51,5 minutes and the mean total bypass time was 89,2 minutes (Table 3 ).

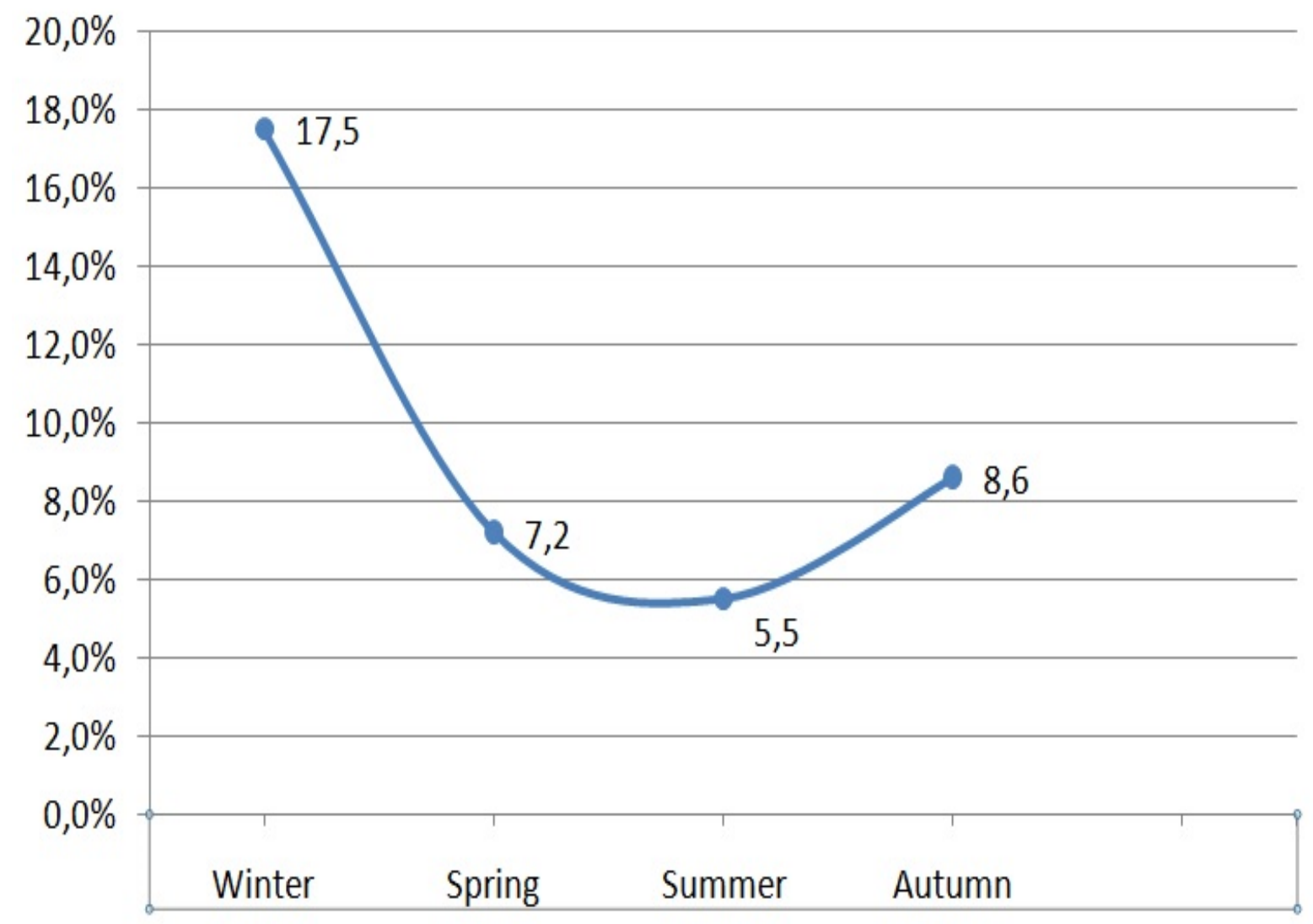

Graph 1: Note the seasonal change in AF development after aortocoronary bypass graft surgery. (AF: Atrial Fibrillation) 
Table 1: Demographic Data of the patients. (ACE: Angiotensin-Converting Enzyme)

\begin{tabular}{lcc}
\hline Demographic Data & $\begin{array}{c}\text { Percentage (\%) } \\
\text { or Mean }(\overline{\mathbf{x}}+\mathbf{s d})\end{array}$ & (n) or min-max \\
\hline Male & 69,2 & 27 \\
Female & 30,8 & 12 \\
Age & $70,2 \pm 7,9$ & $53-85$ \\
Body-mass index $\left(\mathrm{kg} / \mathrm{m}^{2}\right)$ & $27,7 \pm 3,4$ & $20,4-35,4$ \\
Tobacco use & 28,2 & 11 \\
Diabetes Mellitus & 41 & 16 \\
Hypertension & 69,2 & 27 \\
Cerebrovascular disease & 12,8 & 5 \\
Chronic renal disease & 28,2 & 11 \\
Chronic obstructive pulmonary disease & 20,5 & 8 \\
Obstructive sleep apnea & 15,4 & 6 \\
Peripheral artery disease & $\mathbf{2 3 , 1}$ & $\mathbf{9}$ \\
Hyperthyroidism & $\mathbf{1 0 , 3}$ & $\mathbf{4}$ \\
Hypothyroidism & $\mathbf{1 0 , 3}$ & $\mathbf{4}$ \\
Mitral valve failure & $\mathbf{5 , 1}$ & $\mathbf{2}$ \\
Mitral valve stenosis & $\mathbf{5 , 1}$ & $\mathbf{2}$ \\
ACE inhibitor use & $\mathbf{3 0 , 8}$ & $\mathbf{2 0}$ \\
Beta-blocker use & $\mathbf{5 1 , 3}$ & $\mathbf{4}$ \\
Statin use & $\mathbf{1 0 , 3}$ & $\mathbf{1 8}$ \\
Acetylsalicylic acid use & $\mathbf{4 6 , 2}$ & \\
\hline
\end{tabular}

Table 2: Laboratory and echocardiographic data of the patients.

\begin{tabular}{lcc}
\hline Laboratory and echocardiographic data & Mean $(\overline{\mathbf{x}}+\mathbf{s d})$ & Min-Max \\
\hline Estimated glomerular filtration rate $(\mathrm{eGFR})\left(\mathrm{ml} / \mathrm{min} / \mathrm{m}^{2}\right)$ & 71,8 & $20,4-130,4$ \\
Calcium $(\mathrm{mg} / \mathrm{dL})$ & 9,03 & $7,7-10$ \\
Potassium $(\mathbf{m E q} / \mathbf{L})$ & $\mathbf{4 , 2 6}$ & $\mathbf{3 , 4 - 5 , 3 6}$ \\
Ejection fraction $(\%)$ & $\mathbf{4 9 , 9}$ & $\mathbf{3 0 - 6 0}$ \\
Left atrial diameter $\left(\mathbf{c m} / \mathbf{m}^{2}\right)$ & $\mathbf{4 5 , 1}$ & $\mathbf{3 9 - 5 8}$ \\
\hline
\end{tabular}

Table 3: Intraoperative and postoperative data of the patients.

\begin{tabular}{lcc}
\hline Intraoperative and postoperative data & Mean $(\overline{\mathbf{x}}+\mathbf{s d})$ & Min-Max \\
\hline Aorta coronary graft count & 3,2 & $2-4$ \\
Cross clamp time (minutes) & 51,5 & $24-112$ \\
Total bypass time (minutes) & $\mathbf{8 9 , 2}$ & $\mathbf{4 5 - 1 5 6}$ \\
Erythrocyte suspension need (units) & $\mathbf{2 , 2}$ & $\mathbf{0 - 5}$ \\
Fresh frozen plasma needs (units) & $\mathbf{5 , 5}$ & $\mathbf{2 - 1 1}$ \\
The day of postoperative atrial fibrillation & $\mathbf{2 , 9}$ & $\mathbf{1 - 1 2}$ \\
\hline
\end{tabular}




\section{DISCUSSION}

There are many publications in the literature about $\mathrm{AF}$ after coronary artery bypass graft operations. In recent years, these publications have explicitly focused on the possibility that vitamin D deficiency may play a role in the development of postoperative AF. The synthesis of vitamin D is dependent on sunlight. $90 \%$ of vitamin $\mathrm{D}$ synthesis occurs on human skin by ultraviolet (UV) B sunlight. In addition, fish, liver, fish oils, egg yolk, mushrooms, and other products with vitamin D additives are available ${ }^{5}$. The fact that UV-B is the main factor in the synthesis of vitamin D suggests that this synthesis may differ by seasonal. Dogan and colleagues noted that low vitamin D levels were seen most often in the winter and autumn seasons and least in the summer and spring seasons ${ }^{6}$. The seasonal characteristics of vitamin D levels are associated with geographic hemispheres. Indeed, Bolland and colleagues in New Zeland found the opposite result in the northern hemisphere. According to the results in the southern hemisphere, the most frequent months of vitamin D insufficiency were in June, July, and August, while January, February, and March were at least ${ }^{7}$. In regions such as the Antarctic, the level of vitamin D in the winter season was found to be completely poor, and vitamin D support needed ${ }^{8}$. In the study of Lagunova et al.noted that vitamin D level was lowest in winter, increased in spring, peaked in summer and again decreased in autumn 9. In the study of Bouillon et al. in the northern hemisphere also showed that vitamin D levels were lowest during the winter and autumn seasons ${ }^{10}$.

Serum vitamin $D$ levels are defined as deficiency if $<20 \mathrm{ng} / \mathrm{mL}$ and insufficiency if $<30 \mathrm{ng} / \mathrm{mL}$. Vitamin D deficiency has a prevalence of between $25-57 \%$ in the USA (11). There are some risk factors for vitamin D deficiency. These risk factors are; advanced age, darkly pigmented skin, institution or home dependancy, to be far from equator, winter season, cover-up clothing and / or sunscreen, air pollution, smoking, obesity, malabsorption, renal disease, liver disease, medications: such as, anticonvulsants, glucocorticoids, antirejection, and human immunodeficiency virus medications ${ }^{11}$. Vitamin D increases bone density and reduces the risk of bone and tooth fractures, cancer, multiple sclerosis, diabetes mellitus, allergies and asthma, infection, mental illness, kidney disease ${ }^{12}$. It has also been shown to reduce musculoskeletal pain and cardiovascular mortality (12). Vitamin D deficiency is a risk factor for cardiovascular diseases. This risk is explained by endovascularprotective effect mechanism of vitamin D ${ }^{13,14}$.
AF often develops on the second day after coronary artery bypass surgery. In our study, postoperative AF occurred on the 2,9. day, similar to that in the literature. Advanced age, history of atrial fibrillation, hypertension, heart failure, chronic lung disease, right coronary artery lesion, coronary artery disease accompanying valve diseases, metabolic changes, low plasma magnesium level $(<0.95 \mathrm{mmol} / \mathrm{l})$, pre-surgical discontinuation of beta-blocker therapy, inadequate protection of the atrium during surgery, transfusion of blood products are known causes that increase the risk of developing AF during the postoperative period ${ }^{15-}$ ${ }^{18}$. Polat and his colleagues noted that low EF and left primary coronary lesion were severe risk factors for postoperative AF ${ }^{19}$. Şener and colleagues reported that low EF is a predictor of postoperative $\mathrm{AF}^{20}$. In the study of Cerit and colleagues, found low vitamin D levels in patients who developed postoperative AF. However, it was found that low vitamin D level was not valid as a predictor for postoperative $\mathrm{AF}^{3}$.

Beta-blockers, amiodarone, and cardioversion are using in the treatment of postoperative AF. However, amiodarone is most commonly used in postoperative AF. In the study of Çiçekçioğlu and colleagues, they noted that amiodarone was not effective enough in the treatment of postoperative $A F{ }^{21}$. Cerit et al. Investigated the effects of preoperative vitamin $\mathrm{D}$ supplementation on postoperative AF development. According to this study, vitamin D has no impact on preventing postoperative $\mathrm{AF}$ in patients with insufficiency, but it helps to reduce postoperative $\mathrm{AF}$ in patients with a deficiency ${ }^{22}$.

\section{CONCLUSION}

The seasonal change of postoperative AF supports its relationship with vitamin D. However, the development of postoperative AF is multifactorial. Therefore, prospective randomized controlled trials with large populations are needed to fully establish the relationship between postoperative $\mathrm{AF}$ and vitamin $\mathrm{D}$.

\section{REFERENCES}

1. Kupari M, Koskinen P. Seasonal variation in the occurrence of acute atrial fibrillation and relation to air temperature and sale of alcohol. Am J Cardiol 1990;66:1519-20.

2. Watanabe E, Kuno Y, Takasuga H, Tong M, Sobue Y, Uchiyama T, et al. Seasonal variation in paroxysmal atrial fibrillation documented by $24-$ hour Holter electrocardiogram. Heart Rhythm 2007;4:27-31. 
3. Cerit L, Kemal H, Gulsen K, Ozcem B, Cerit Z, Duygu H. Relationship between vitamin $D$ and the development of atrial fibrillation after on-pump coronary artery bypass graft surgery. Cardiovasc J Afr 2017;28:104-7.

4. Emren SV, Aldemir M, Ada, F. Does deficiency of vitamin $d$ increase new-onset atrial fibrillation after coronary artery bypass grafting surgery? Heart Surg Forum 2016;19(4):180-4.

5. Pearce SH, Cheetham TD. Diagnosis and management of vitamin D deficiency. BMJ 2010; 340: b5664.

6. Dogan N, Colak A, Guden N, Ustuner F. Vitamin D deficiency in children in Aegean Region in Turkey. Cumhuriyet Med J 2015;37(1):17-22.

7. Bolland MJ, Chiu WW, Davidson JS, Grey A, Bacon C, Gamble GD, et al. The effects of seasonal variation of 25-hydroxyvitamin $\mathrm{D}$ on the diagnosis of vitamin D insufficiency. N Z Med J. 2008 28;121(1286):63-74.

8. Smith SM, Gardner KK, Locke J, Zwart R. Vitamin D supplementation during Antarctic winter. Am J Clin Nutr, 2009;89(4):1092-8.

9. Lagunova Z, Porojnicu AC, Lindberg F, Hexeberg S, Moan J. The dependency of vitamin D status on body mass index, gender, age, and season. Anticancer Res 2009; 29: 3713-20.

10. Bouillon RA, Auwerx JH, Lissens WD, Pelemans WK. Vitamin D status in the elderly: seasonal substrate deficiency causes 1,25dihydroxycholecalciferol deficiency. Am J Clin Nutr 1987;45:755-63.

11. Lee JH, O'Keefe JH, Bell D, Hensrud DD, Holick MF. Vitamin D deficiency an important, common, and easily treatable cardiovascular risk factor? J Am Coll Cardiol 2008;52(24):1949-56.

12. Thacher TD, Clarke BL. Vitamin D insufficiency. Mayo Clin Proc 2011;86:50 -60.

13. Judd S, Tangpricha V. Vitamin D Deficiency and Risk for Cardiovascular Disease. Circulation 2008;117(4):503-11.
14. Zitterman A. Vitamin D and disease prevention with special reference to cardiovascular disease. Prog Biophys Mol Biol 2006;92:39-48.

15. Katariya K, DeMarchena E, Bolooki H. Oral amiodarone reduces the incidence of postoperative atrial fibrillation. Ann Thorac Surg 1999;68:1599603.

16. Ommen SR, Odell JA, Stanton MS. Atrial arrhythmias after cardiothoracic surgery. N Engl J Med 1997;336:1429-34.

17. Yağdı T, Nalbantgil S, Ayık F, Apaydın A, İslamoğlu $\mathrm{F}$, Posacioğlu $\mathrm{H}$, et al. Amiodarone reduces the incidence of atrial fibrillation after coronary artery bypass grafting. J Thorac Cardiovasc Surg 2003;125:1420-5.

18. Koch CG, Li L, Van Wagoner DR, Duncan AI, Gillinov AM, Blackstone EH. Red cell transfusion is associated with an increased risk for postoperative atrial fibrillation. Ann Thorac Surg 2006;82:1747-56.

19. Polat A, Şahin İ, Yücel C, Önür İ, Dinçkal H, Erentuğ V. Coronary vasculature and postoperative atrial fibrillation: a risk factor analysis. Turk Gogus Kalp Dama 2013;21(3):567-73.

20. Sener E, Göl MK, Yapici F, Zorlutuna Y, Tasdemir O, Bayazit K. Koroner Bypass Yapılan Olgularda Postoperatif Dönemde Gelișen Atrial Fibrilasyonun Nedenlerinin Araştırılması. Turk J Cardiol 1993;6:79-83.

21. Çiçekçioğlu F, Kervan Ü, Parlar Aİ, Ersoy Ö, Bardakçı H, Ulus AT, et al. Koroner bypass cerrahisinden sonra gelişen atriyal fibrilasyon tedavisinde amiodaronun etkinliği. Turk Gogus Kalp Dama 2009;17(2):77-82.

22. Cerit L, Ozcem B, Cerit Z, Duygu H. Preventive Effect of Preoperative Vitamin D Supplementation on Postoperative Atrial Fibrillation. Braz J Cardiovasc Surg. 2018;33(4):347-52. 